\title{
Perbandingan Antiseptik Chlorhexidine Alkohol dengan Povidone Iodine terhadap Penurunan Pertumbuhan Koloni Bakteri pada Kateter Epidural yang Dipasang di Kamar Operasi Rumah Sakit Dr. Hasan Sadikin Bandung
}

\author{
Andie Muhari Barzah, ${ }^{1}$ Erwin Pradian, ${ }^{2}$ Tatang Bisri ${ }^{2}$ \\ ${ }^{1}$ Bagian Anestesi dan Terapi Intensif Rumah Sakit Siloam Kupang, \\ ${ }^{2}$ Departemen Anestesiologi dan Terapi Intensif \\ Fakultas Kedokteran Universitas Padjadjaran/Rumah Sakit Dr. Hasan Sadikin Bandung
}

\begin{abstract}
Abstrak
Chlorhexidine alkohol dan povidone iodine digunakan sebagai zat antiseptik pada anestesi epidural. Aseptik dan antiseptik sebelum tindakan epidural harus dilakukan secara optimal untuk menurunkan komplikasi infeksi pascatindakan. Tujuan penelitian ini menilai perbedaan penurunan pertumbuhan koloni bakteri pada kateter epidural di Rumah Sakit Dr. Hasan Sadikin Bandung. Penelitian single blind randomized controlled trials pada 76 pasien yang dilakukan anestesi epidural di Rumah Sakit Dr. Hasan Sadikin Bandung pada bulan November 2014-Februari 2015. Subjek penelitian dibagi menjadi 2 kelompok, yaitu chlorhexidine alkohol dan povidone iodine. Dilakukan pemeriksaan kultur apus kulit sebelum dan sesudah tindakan aseptik dan antiseptik kemudian dilakukan pemeriksaan kultur kateter epidural pada hari ke-3 setelah pemasangan. Data hasil penelitian dianalisis dengan menggunakan uji-t, chi-kuadrat, dan Uji Mann-Whitney. Hasil penelitian ini didapatkan kultur positif bakteri dari pemeriksaan sebelum tindakan aseptik dan antiseptik 33 dari 38 pada chlorhexidine alkohol dan 35 dari 38 pada povidone iodine. Kultur positif bakteri menjadi 4 dari 38 pada chlorhexidine alkohol dan povidone iodine setelah pemberian aseptik dan antiseptik. Kultur pascapemasangan kateter epidural positif bakteri 7 dari 38 pada chlorhexidine alkohol dan 5 dari 38 pada povidone iodine $(\mathrm{p}<0,05)$. Simpulan penelitian ini menunjukkan zat antiseptik chlorhexidine alkohol lebih lebih rendah pertumbuhan kumannya bila dibanding dengan povidone iodine pada kateter epidural.
\end{abstract}

Kata kunci: Antiseptik, chlorhexidine alkohol, povidone iodine

\section{Comparison between Chlorhexidine-Alcohol and Povidone Iodine in Reducing Catheter Tip Bacterial Colonization in Dr. Hasan Sadikin General Hospital Bandung}

\begin{abstract}
Chlorhexidine-alcohol and povidone iodine are commonly used as antiseptic solutions in epidural anesthesia. Aseptic and antiseptic procedures must be performed before any epidural procedure to lower infection complications after the procedure. The objective of this study was to investigate the lowest bacterial growth on epidural catheter after chlorhexidine-alcohol or povidone iodine application as the antiseptic solution in Dr. Hasan Sadikin General Hospital Bandung. This was a single blind randomized controlled trial on 78 patients underwent epidural anesthesia in the period of November 2014-February 2015. The subjects were divided in to 2 groups, each consisted of 38 patients. Aseptic and antiseptic procedures were performed using chlorhexidine-alcohol or povidone iodine with skin swab culture collected before and after the procedure. Epidural catheter culture was performed in the 3rd days after the installment. Data were analyzed using t-test, chi-square test, and Mann Whitney test. The result of this study showed positive bacterial cultures prior to aseptic and antiseptics, 33 from 38 in chlorhexidine-alcohol and 35 from 38 in povidone iodine. Positive bacterial cultures became 4 from 38, both in chlorhexidine-alcohol and povidone iodine. Positive bacterial culture on the 3rd days after epidural catheter placement was 7 from 38 after chlorhexidine-alcohol and 5 from 38 after povidone iodine $(\mathrm{p}<0.05)$. It is concluded that the ability of chlorhexidine-alcohol to reduce bacterial growth on epidural catheter is lower than povidone-iodine with regards to reducing infection after catheter epidural installment.
\end{abstract}

Key words: Antiseptic, chlorhexidine-alcohol, povidone iodine

Korespondensi: Andie Muhari Barzah, dr., SpAn, Bagian Anestesi dan Terapi Intensif Rumah Sakit Siloam kupang, Jl. R. W. Monginsidi, kel. Fatulili Kec. Oebobo, Kota Kupang, NTT, Tlpn 0380-8530900, Mobile 08157043819/085317771666, Emaildjmonid@gmail.com 


\section{Pendahuluan}

Optimalisasi tindakan aseptik dan antiseptik sebelum tindakan operasi dapat menurunkan kejadian infeksi setelah tindakan. Infeksi pada tempat operasi terjadi sebanyak 300.000500.000 kasus setiap tahunnya di Amerika sehingga diharapkan dengan usaha perbaikan tindakan aseptik dan antiseptik pada kulit akan menurunkan kejadian infeksi. ${ }^{1}$ Komplikasi infeksi dapat terjadi pada tindakan anestesia epidural. Infeksi pada anestesia epidural dapat meningkatkan morbiditas dan juga mortalitas sehingga diperlukan strategi pencegahan dengan tindakan aseptik dan antiseptik yang baik. $^{2}$

Teknik aseptik yang adekuat sebelum tindakan anestesia epidural sangat diperlukan untuk mengurangi angka kejadian komplikasi infeksi. Konsep pentingnya tindakan aseptik masih menjadi perdebatan. Suatu penelitian menyatakan bahwa selain teknik yang adekuat, harus disertai dengan tindakan cuci tangan, melepaskan perhiasan di jari dan juga tangan, penggunaan sarung tangan steril, pakaian steril, masker, dan penggunaan filter bakteri. ${ }^{3}$

Tindakan anestesi epidural yang dikerjakan di Rumah Sakit Dr. Hasan Sadikin Bandung tercatat sebanyak 573 pada tahun 2013 dan tidak terdokumentasi kejadian komplikasi infeksi selama perawatan setelah pemasangan kateter epidural. ${ }^{4}$ Penelitian pemetaan bakteri di Rumah Sakit Dr. Hasan Sadikin Bandung tahun 2014 mendapatkan bahwa 26,93\% tip kateter epidural tumbuh koloni bakteri dan $50 \%$ di antaranya merupakan flora normal tubuh. $^{5}$

Infeksi yang berkaitan dengan anestesia regional dan terapi nyeri dapat menyebabkan komplikasi antara lain berupa infeksi. Faktor risiko yang berhubungan dengan infeksi adalah riwayat sepsis yang pernah terjadi sebelumnya, diabetes melitus, imunodefisiensi, penggunaan kortikosteroid, kolonisasi bakteri yang terlokalisir, dan penggunaan kateter yang lama. Beberapa kasus infeksi seperti abses epidural merupakan kasus yang serius dan mengancam jiwa jika tidak didiagnosis dan diterapi dengan segera. ${ }^{6,7}$

Analgesia epidural efektif dipergunakan untuk mengatasi nyeri pascabedah. Analgesia epidural dapat digunakan selama dua sampai tiga hari pascabedah, tetapi karena kateter epidural menghubungkan antara tubuh dan dunia luar maka dapat menjadi pintu masuk kuman penyebab infeksi. Hal ini dapat dicegah dengan mematuhi aturan sterilitas yang sudah baku berlaku di rumah sakit. ${ }^{3,8}$

Seorang anestesiolog dapat menyebabkan kejadian infeksi nosokomial dengan membawa mikroorganisme ke dalam susunan saraf pusat karena tidak mengikuti prosedur teknik tindakan aseptik dan antiseptik. ${ }^{2,9}$ Penelitian tentang koloni bakteri pada kateter epidural menunjukkan bahwa 10,5\% kateter epidural terkontaminasi oleh flora normal pada kulit manusia dan bakteri yang patogen. ${ }^{7}$

Jumlah pemasangan kateter epidural pada Februari 2014 di Rumah Sakit Dr. Hasan Sadikin Bandung adalah 52 pasien. Sebanyak $26,93 \%$ dari tip/ujung kateter epidural yang terpasang tersebut terinfeksi oleh bakteri. Staphylococcus epidermidis merupakan bakteri yang paling sering ditemukan pada tip kateter epidural yang dipasang untuk penanganan nyeri pascaoperasi pada bulan Februari 2014 di Rumah Sakit Dr. Hasan Sadikin Bandung. ${ }^{5}$

Penelitian yang dilakukan dengan evaluasi pasien selama 30 hari yang dilakukan pada 849 pasien di Houston, Amerika Serikat, kejadian infeksi pada tempat operasi lebih rendah pada biakan kulit dengan chlorhexidine dibanding dengan povidone iodine. ${ }^{1}$ Penelitian yang telah dilakukan di New York, Amerika Serikat yang menggunakan povidone iodine dan chlorhexidine alkohol untuk tindakan aseptik dan antiseptik pada pasien yang akan dioperasi baik bedah maupun kebidanan, didapatkan bahwa penggunaan chlorhexidine alkohol lebih efektif bila dibanding dengan penggunaan povidone iodine. ${ }^{10}$

Penelitian di Perancis dengan menggunakan povidone iodine dan chlorhexidine alkohol pada tindakan aseptik dan antiseptik pada pemasangan kateter vena sentral didapatkan hasil bahwa penggunaan chlorhexidine alkohol 
lebih efektif bila dibanding dengan pemakaian povidone iodine. ${ }^{11}$

Penelitian di Mumbai, India, terhadap 60 pasien mempergunakan povidone iodine atau chlorhexidine alkohol untuk tindakan aseptik dan antiseptik pada pasien yang dilakukan anestesia epidural dan juga pada pasien yang dilakukan pemasangan kateter vena sentral, didapatkan hasil bahwa tidak ada perbedaan antara kedua antiseptik tersebut baik dari segi biaya, efektivitas, maupun efek samping. ${ }^{12}$

Penelitian lain dilakukan pada 98 pasien berdasarkan hasil pemeriksaan bakteriologis didapatkan angka pertumbuhan bakteri pada sampel biakan kulit dengan chlorhexidine lebih rendah dibanding dengan povidone iodine pada pemasangan kateter vena, saat pengambilan contoh darah, dan pada pemasangan kateter epidural pada anak. ${ }^{13}$

Efektivitas cairan aseptik dan antiseptik antara chlorhexidine alkohol dan povidone iodine masih kontroversi. Tujuan utama aseptik dan antiseptik adalah menghilangkan bakteri transien, bakteri patogen, dan mengurangi flora normal kulit untuk mengurangi risiko infeksi. ${ }^{14}$

Tujuan penelitian ini adalah menilai penurunan pertumbuhan koloni bakteri antara antiseptik chlorhexidine alkohol dan povidone iodine pada kateter epidural yang dipasang di kamar operasi Rumah Sakit Dr. Hasan Sadikin Bandung.

\section{Subjek dan Metode}

Subjek penelitian adalah semua pasien yang dilakukan tindakan anestesia epidural pada operasi elektif ataupun operasi emergensi di kamar operasi Rumah Sakit Dr. Hasan Sadikin Bandung dengan usia minimal 18 tahun. Kriteria eksklusi adalah terdapat riwayat alergi terhadap penggunaan antiseptik sebelumnya.

Kriteria pengeluaran adalah pasien pulang paksa atau meninggal selama perawatan di ruang rawat Rumah Sakit Dr. Hasan Sadikin Bandung sebelum waktu pencabutan kateter epidural. Faktor perancu adalah penggunaan antibiotik profilaksis sebelum tindakan.

Banyaknya sampel yang diambil berdasar atas rumus perbedaan proporsi efektivitas tindakan, tingkat kepercayaan 95\%, dan besar uji kekuatan $90 \%$ sehingga didapatkan sampel 34 orang untuk tiap kelompok perlakuan. Jumlah sampel ditambah 10\% kemungkinan pengeluaran sampel sehingga jumlah sampel tiap kelompok adalah 38 orang.

Penelitian dilakukan di Rumah Sakit Dr. Hasan Sadikin Bandung dari bulan November 2014 sampai dengan Februari 2015. Penelitian dimulai setelah disetujui oleh Komite Etik Penelitian Kesehatan Rumah Sakit Dr. Hasan Sadikin (RSHS) Bandung/Fakultas Kedokteran Universitas Padjadjaran.

Penelitian dilakukan dengan single blind randomized controlled trials. Pasien dibagi 2 kelompok, yaitu kelompok C (chlorhexidine alkohol) dan kelompok $\mathrm{P}$ (povidone iodine). Sebelum dilakukan tindakan aseptik dan antiseptik, semua subjek penelitian diberikan antibiotik preoperatif pada saat di ruang perawatan. Golongan antibiotik profilaksis yang diberikan adalah sefalosporin generasi ke-3. Pada kelompok C dilakukan tindakan aseptik dan antiseptik sebelum pemasangan kateter epidural menggunakan chlorhexidine alkohol, sedangkan kelompok $\mathrm{P}$ dilakukan tindakan aseptik dan antiseptik sebelum pemasangan kateter epidural dengan memakai povidone iodine.

Dilakukan swab I sebelum pemberian cairan aseptik dan antiseptik di tempat penyuntikan jarum epidural, kemudian dimasukkan ke dalam tabung steril pemeriksaan I. Dilakukan pemberian cairan aseptik dan antiseptik di daerah tindakan dan dibiarkan mengering. Cara pemberian cairan aseptik dan antiseptik adalah diberikan cairan pada titik penusukan jarum epidural dilanjutkan dengan gerakan melingkar ke arah luar tanpa terputus hingga menutupi daerah steril pada kain doek bolong.

Setelah cairan aseptik dan antiseptik tersebut kering, tempat penyuntikan ditutup menggunakan kain/doek bolong. Dilakukan swab II dan dimasukkan ke dalam tabung steril pemeriksaan II. Selanjutnya, dilakukan insersi jarum epidural serta insersi kateter epidural, luka tempat penyuntikan ditutup dengan plester steril transparan. Dilakukan 
Tabel 1 Nilai Rata-rata dan Standar Deviasi Jenis Kelamin dan Usia Subjek Penelitian pada Tiap Kelompok

\begin{tabular}{lccc}
\hline \multicolumn{1}{c}{ Karakteristik } & $\begin{array}{c}\text { Chlorhexidine Alkohol } \\
(\mathbf{n = 3 8 )}\end{array}$ & $\begin{array}{c}\text { Povidone Iodine } \\
(\mathbf{n = 3 8 )}\end{array}$ & Nilai p \\
\hline Jenis kelamin & 18 & 13 & $0,243^{*}$ \\
$\quad$ Laki-laki & 20 & 25 & \\
Perempuan & & & \\
Usia (tahun) & 45,61 & 48,03 & $0,916^{* *}$ \\
Rata-rata & 14,50 & 15,39 & \\
Std. deviation & & & \\
Jenis operasi & 5 & 7 & \\
Bedah umum & 15 & 17 & $0,532^{*}$ \\
Obstetri dan ginekologi & 8 & 3 & \\
Ortopedi & 10 & 11 & \\
Urologi & & & \\
\hline
\end{tabular}

pemeriksaan biakan bakteri dari tabung I dan tabung II. Luka penusukan jarum epidural ditutup menggunakan penutup luka transparan.

Saat pascabedah diberikan obat anestesia epidural menggunakan obat yang diencerkan dalam alat suntik sekali pakai. Obat anestesia epidural yang digunakan diganti setiap hari bersamaan dengan alat suntiknya. Pada hari ke-3 dilakukan pencabutan kateter epidural dengan sebelumnya mengoleskan jenis cairan aseptik dan antiseptik sesuai kelompok pasien dan dibiarkan mengering. Setelah kateter epidural terangkat, dilakukan pemotongan tip kateter menggunakan gunting steril dan tip kateter tersebut dimasukkan ke dalam tabung steril pemeriksaan III. Selanjutnya dilakukan pemeriksaan biakan bakteri dari tabung III.

Data dianalisis menggunakan uji-t untuk membandingkan perbedaan dua rata-rata, uji chi-kuadrat untuk membandingkan perbedaan dua proporsi data kualitatif, dan Uji MannWhitney untuk membandingkan proporsi. Perhitungan dan analisis data menggunakan statistical product and service solution (SPSS) 17.0 for windows. Taraf signifikansi $5 \%$ dan dianggap bermakna bila $\mathrm{p}<0,05$.

\section{Hasil}

Penelitian dilakukan terhadap 76 orang subjek penelitian. Setiap kelompok terdiri atas 38 orang. Usia rata-rata subjek penelitian adalah 45,61 tahun pada chlorhexidine alkohol dan 48,03 tahun pada povidone iodine. Jenis operasi yang dilakukan dengan menggunakan anestesi epidural pada kedua kelompok, yaitu pada operasi bedah umum, obstetri dan ginekologi, ortopedi, dan urologi. Berdasarkan uji-t tidak terdapat perbedaan bermakna antara jenis kelamin, usia, dan jenis operasi antara kedua kelompok ( $p>0,05$; Tabel 1).

Tabel 2 Karakteristik Antibiotik yang Dipergunakan Sebelum Tindakan Epidural

\begin{tabular}{lccc}
\hline \multicolumn{1}{c}{ Antibiotik Profilaksis } & $\begin{array}{c}\text { Chlorhexidine Alkohol } \\
(\mathbf{n = 3 8 )}\end{array}$ & $\begin{array}{c}\text { Povidone Iodine } \\
(\mathbf{n}=\mathbf{3 8})\end{array}$ & Nilai p \\
\hline Cefixime & 3 & 2 & $0,106^{*}$ \\
Cefotaxime & 8 & 3 & \\
Ceftriaxon & 27 & 33 & \\
\hline
\end{tabular}


Tabel 3 Sebaran Pertumbuhan Bakteri pada Biakan Kulit Sebelum Pemberian Antiseptik

\begin{tabular}{lccc}
\hline \multicolumn{1}{c}{ Pertumbuhan } & $\begin{array}{c}\text { Chlorhexidine Alkohol } \\
(\mathbf{n = 3 8 )}\end{array}$ & $\begin{array}{c}\text { Povidone Iodine } \\
(\mathbf{n = 3 8 )}\end{array}$ & Nilai p \\
\hline Tumbuh & 33 & 35 & \\
Sedikit & 7 & 5 & \\
Sedang & 9 & 8 & $0,710^{*}$ \\
Banyak & 17 & 22 & \\
Tidak tumbuh & 5 & 3 & \\
\hline
\end{tabular}

Antibiotik yang diberikan sebelum tindakan anestesia epidural pada kedua kelompok berdasarkan uji-t dinyatakan tidak berbeda bermakna $(\mathrm{p}>0,05)$. Antibiotik yang diberikan, yaitu salah satu dari cefixime, cefotaxime, dan ceftriaxone. Tidak terdapat pemberian antibiotik ganda (Tabel 2).

Hasil analisis statistik dengan Uji MannWhitney menunjukkan sebaran pertumbuhan bakteri kedua kelompok sebelum diberikan zat antiseptik tidak berbeda bermakna $(p>0,05$; Tabel 3). Karakteristik hasil kultur bakteri sebelum tindakan pemberian antiseptik dapat dilihat pada Tabel 4 .

Hasil analisis statistik dengan Uji MannWhitney menunjukkan sebaran pertumbuhan bakteri pada kedua kelompok zat antiseptik yang diberikan setelah pemberian antiseptik tidak berbeda bermakna ( $p>0,05$; Tabel 5). Gambaran karakteristik hasil kultur bakteri sesudah tindakan pemberian antiseptik dapat dilihat pada Tabel 6 .

Hasil analisis statistik dengan Uji MannWhitney menunjukkan bahwa biakan tip kateter epidural yang tumbuh pada hari ke-3 pada kelompok povidone iodine lebih banyak dengan perbedaan bermakna $(\mathrm{p}<0,05$; Tabel 7). Gambaran karakteristik hasil kultur bakteri pada biakan tip kateter epidural hari ke-3 pemasangan terdapat pada Tabel 8.

\section{Pembahasan}

Data demografi jenis kelamin, usia, dan jenis operasi yang didapatkan pada kedua kelompok perlakuan adalah homogen sehingga dapat dibandingkan (Tabel 1). Antibiotik profilaksis yang diberikan untuk mencegah pertumbuhan bakteri komensal dan patogen pada daerah operasi, kulit pada tempat insersi epidural, dan mencegah infeksi akibat penyebaran hematogen. Antibiotik yang diberikan adalah

Tabel 4 Karakteristik Hasil Kultur Sebelum Tindakan Pemberian Antiseptik

\begin{tabular}{lclc}
\hline \multicolumn{1}{c}{$\begin{array}{c}\text { Chlorhexidine Alkohol } \\
\text { (n=38) }\end{array}$} & \multicolumn{1}{c}{$\begin{array}{c}\text { Povidone Iodine } \\
\text { (n=38) }\end{array}$} \\
\hline \multicolumn{1}{c}{ Jenis Bakteri } & Jumlah & \multicolumn{1}{c}{ Jenis Bakteri } & Jumlah \\
\hline Acinetobacter baumannii & 3 & Acinetobacter baumannii & 3 \\
Burkholderia cepacia & 4 & Bacillus spp & 2 \\
Enterobacter aerogenes & 2 & Burkholderia cepacia & 2 \\
Enterobacter cloacae & 1 & Enterobacter aerogenes & 9 \\
Psuedomonas aeruginosa & 2 & Rhizobium radiobacter & 5 \\
Rhizobium radiobacter & 1 & Staphylococcus xylosus & 1 \\
Staphylococcus aureus & 3 & Staphylococcus epidermidis & 7 \\
Staphylococcus cohnii & 1 & Staphylococcus haemoliticus & 6 \\
Staphylococcus xylosus & 2 & Steril & 3 \\
Staphylococcus epidermidis & 6 & & \\
Staphylococcus haemoliticus & 10 & & \\
Steril & 3 & & \\
\hline
\end{tabular}


Tabel 5 Sebaran Pertumbuhan Bakteri pada Biakan Kulit Setelah Pemberian Antiseptik

\begin{tabular}{lccc}
\hline \multicolumn{1}{c}{ Pertumbuhan } & $\begin{array}{c}\text { Chlorhexidine Alcohol } \\
(\mathbf{n = 3 8 )}\end{array}$ & $\begin{array}{c}\text { Povidone Iodine } \\
(\mathbf{n = 3 8 )}\end{array}$ & Nilai p \\
\hline Tumbuh & 4 & 4 & \\
Sedikit & 1 & 1 & $1,000^{*}$ \\
Sedang & 2 & 2 & \\
Banyak & 1 & 1 & \\
Tidak tumbuh & 34 & 34 & \\
Nilai p & $0,259^{* *}$ & $0,259^{* *}$ & \\
\hline
\end{tabular}

golongan yang sama dan diberikan sebelum dilakukan tindakan. Antibiotik yang diberikan dinyatakan homogen sehingga faktor perancu pada penelitian ini dapat disingkirkan (Tabel 2).

Pemeriksaan apus kulit yang dilakukan sebelum tindakan antiseptik menggambarkan flora kulit yang ada pada saatitu. Hampir semua pemeriksaan didapatkan bakteri. Bakteri yang diidentifikasi adalah homogen untuk kedua perlakuan. Bakteri yang didapatkan merupakan flora normal dan bakteri komensal pada kulit (Tabel 3).

Hubungan antara flora normal dan inang berupa hubungan parasitik, komensal, atau mutualisme. Bakteri di permukaan kulit yang jarang berhubungan dengan penyakit yang terjadi dinamakan bakteri komensal. ${ }^{15}$

Terdapat lima sampel apusan dari kelompok chlorhexidine dan tiga sampel dari kelompok povidone iodine dengan hasil tidak terdapat pertumbuhan bakteri. Hasil ini kemungkinan disebabkan oleh pengambilan sampel yang salah dan atau pengenceran pemeriksaan apus yang lebih cair. ${ }^{16}$

Pemeriksaan apus kulit setelah diberikan antiseptik chlorhexidine alkohol dan povidone iodine menunjukkan bahwa masing-masing zat memiliki kemampuan yang sama untuk membunuh bakteri (Tabel 5).

Chlorhexidine yang memiliki bentuk dasar chlorhexidine gluconate merupakan biosida spektrum luas yang efektif terhadap jamur, bakteri gram positif, dan bakteri gram negatif. Chlorhexidine me-non-aktifkan mikrob lebih banyak bila dibanding dengan antimikrob lain (antara lain antibiotik) dan mempunyai kemampuan menghancurkan mikrob lebih cepat dibanding dengan antimikrob lain. Chlorhexidine bersifat bakteriostatik dan juga bakterisida yang menghancurkan bakteri dengan mengubah permeabilitas dinding sel dan mengendapkan komponen membran sel serta sitoplasma. Kemampuan chlorhexidine menghancurkan hampir 100\% bakteri gram positif dan negatif dalam waktu 30 detik sehingga dapat mengurangi infeksi oportunis. ${ }^{3}$

Menggabungkan alkohol dengan produk lain akan mengurangi waktu penguapannya. Penambahan isopropil alkohol pada larutan chlorhexidine mempercepat efek bakterisidal. Bentukan senyawa chlorhexidine alkohol akan meningkatkan kemampuan chlorhexidine untuk menembus hingga ke stratum korneum

Tabel 6 Karakteristik Hasil Kultur Sesudah Tindakan Pemberian Antiseptik

\begin{tabular}{lclc}
\hline \multicolumn{1}{c}{$\begin{array}{c}\text { Chlorhexidine Alkohol } \\
\text { (n=38) }\end{array}$} & \multicolumn{1}{c}{$\begin{array}{c}\text { Povidone Iodine } \\
\text { (n=38) }\end{array}$} \\
\hline \multicolumn{1}{c}{ Jenis Bakteri } & Jumlah & \multicolumn{1}{c}{ Jenis Bakteri } & Jumlah \\
\hline Burkholderia cepacia & 1 & Burkholderia cepacia & 1 \\
Enterobacter cloacae & 1 & Enterobacter aerogenes & 1 \\
Rhizobium radiobacter & 1 & Klebsiella pneumoniae & 1 \\
Staphylococcus haemoliticus & 1 & Staphylococcus hominis & 1 \\
\hline
\end{tabular}


Tabel 7 Sebaran Pertumbuhan pada Biakan Tip Kateter Epidural Hari ke-3 Pemasangan

\begin{tabular}{lccc}
\hline \multicolumn{1}{c}{ Pertumbuhan Biakan } & $\begin{array}{c}\text { Chlorhexidine Alkohol } \\
(\mathbf{n}=\mathbf{3 8})\end{array}$ & $\begin{array}{c}\text { Povidone Iodine } \\
(\mathbf{n = 3 8})\end{array}$ & Nilai p \\
\hline Tumbuh & 7 & 24 & \\
Sedikit & 1 & 1 & $0,000^{*}$ \\
Sedang & 1 & 0 & \\
Banyak & 5 & 23 & \\
Tidak tumbuh & 31 & 14 & \\
Nilai p & $0,050^{* *}$ & $0,010^{* *}$ & \\
\hline
\end{tabular}

dan menambah masa aktif beberapa jam. Jarang didapatkan resistensi bakteri terhadap chlorhexidine. ${ }^{3}$

Povidone iodine adalah biosida spektrum luas dengan kelarutan lebih tinggi dibanding dengan campuran iodine lain seperti tincture dan lugol. Povidone iodine dapat dilarutkan dalam ethyl alcohol, isopropyl alcohol, glycols, glycerin, acetone, serta polyethylene glycol. Povidone-iodine efektif pada $\mathrm{pH} 3-6 .{ }^{17}$

Povidone iodine mudah sekali meninggalkan bekas dan dapat mengiritasi kulit. Povidone iodine merupakan antiseptik berpelarut air yang sangat stabil terhadap kelembaban dan cahaya pada penyimpanan, tetapi tidak stabil dengan bentuk iodine-nya. Terdapat beberapa bentuk ion iodine di dalam larutan dan melokul iodine $\left(\mathrm{I}_{2}\right)$ tersebut yang bertanggung jawab terhadap efek antimikrob. ${ }^{18}$

Povidone iodine berbeda dari iodine povidone iodine memiliki tingkat iritasi ringan pada kulit dan tidak memerlukan iodida atau alkohol untuk melarutkannya. Iodine bebas pada cairan povidone iodine sangat sedikit. Hal ini menujukkan bahwa povidone iodine memiliki toksisitas dan kemampuan untuk menghancurkan bakteri yang lebih rendah. ${ }^{19}$

Untuk membedakan fungsi bakterisidalnya bergantung pada konsentrasi iodine bebasnya. Pada formula farmasinya mengandung iodine dan iodida, efek bakterisidalnya bergantung pada molekul iodine bebas. Povidine iodine efektif membunuh bakteri dalam waktu sekitar 1 menit. ${ }^{19}$

Berdasar atas hasil penelitian tentang abses pada epidural dinyatakan bahwa risiko infeksi epidural yang berkaitan dengan kateter lebih rendah pada penggunaan kateter kurang dari 3 hari. Penggunaan yang lebih lama akan meningkatkan risiko infeksi. Risiko kolonisasi

Tabel 8 Karakteristik Hasil Kultur Tip Kateter Epidural Hari ke-3 Pemasangan

\begin{tabular}{lclc}
\hline \multicolumn{1}{c}{$\begin{array}{c}\text { Chlorhexidine Alcohol } \\
\text { (n=38) }\end{array}$} & \multicolumn{1}{c}{$\begin{array}{c}\text { Povidone Iodine } \\
\text { (n=38) }\end{array}$} \\
\hline \multicolumn{1}{c}{ Jenis Bakteri } & Jumlah & \multicolumn{1}{c}{ Jenis Bakteri } & Jumlah \\
\hline Acinetobacter baumannii & 1 & Acinetobacter baumannii & 4 \\
Bacillus spp & 1 & Bacillus spp & 2 \\
Burkholderia cepacia & 2 & Burkholderia cepacia & 3 \\
Enterobacter cloacae & 2 & Enterobacter cloacae & 1 \\
Pseudomonas aeruginosa & 1 & Pseudomonas aeruginosa & 1 \\
Steril & 31 & Enterobacter aerogenes & 2 \\
& & Klebsiella pneumoniae & 3 \\
& & Staphylococcus epidermidis & 2 \\
& & Staphylococcus xylosus & 2 \\
& & Staphylococcus hominis & 1 \\
& & Staphylococcus haemoliticus & 3 \\
\end{tabular}


bakteri didapatkan setelah penggunaan kateter lebih dari 5 hari dan dapat mengakibatkan infeksi sebanyak 85\%.

Pemeriksaan kultur tip kateter epidural hari ke-3, antiseptik chlorhexidine alkohol menujukkan pertumbuhan bakteri yang lebih sedikit dibanding dengan povidone iodine pada kateter epidural $(\mathrm{p}<0,05$; Tabel 7).

Chlorhexidine memiliki efek mengendap di kulit dan tidak mengiritasi. Tidak seperti antimikrob lain, chlorhexidine menunjukkan efektivitas terhadap bentuk lain dari mikrob termasuk spora, protozoa, dan menghancurkan virus yang berkapsul. Chlorhexidine aktif sekitar 48 jam di kulit dan tidak dipengaruhi oleh cairan tubuh lain dan dapat diaplikasikan untuk implan, kateter vena, dan alat medis lain, sedangkan povidone iodine dipengaruhi oleh cairan tubuh dan memiliki efek residu minimal sehingga tidak bertahan lama di kulit. ${ }^{17,19}$

Kontaminasi kateter epidural oleh flora kulit pada tempat insersi merupakan penyebab utama infeksi. Kontaminasi dapat disebabkan tindakan aseptik dan antiseptik yang kurang baik pada saat pemasangan. Mekanisme lain masuknya bakteri melalui obat-obatan atau cairan yang terinfeksi.

Teknik aseptik yang adekuat sebelum tindakan anestesia epidural sangat diperlukan untuk mengurangi angka kejadian komplikasi infeksi. Infeksi pada anestesia epidural dapat meningkatkan morbiditas serta mortalitas sehingga diperlukan strategi pencegahan dengan cara melakukan tindakan aseptik dan antiseptik yang baik. ${ }^{2,3,20}$

Hasil penelitian ini diharapkan memberikan informasi ilmiah yang bermanfaat mengenai efektivitas chlorhexidine alkohol terhadap pertumbuhan bakteri pada ujung kateter epidural.

\section{Simpulan}

Berdasarkan hasil penelitian ini didapatkan simpulan bahwa pada kelompok chlorhexidine alkohol pertumbuhan bakteri pada biakan kateter epidural hari ke-3 pemasangan lebih rendah dibanding dengan penggunaan povidone iodine. Jenis bakteri yang didapatkan pada penggunaan larutan chlorhexidine alkohol lebih sedikit dibanding dengan penggunaan povidone iodine. Hasil penelitian sesuai dengan rekomendasi American Society of Anesthesiologists (ASA) dan Central for Disease Control (CDC) untuk tindakan preparasi kulit sebelum dilakukannya tindakan medis invasif untuk mencegah infeksi.

Berdasarkan hasil penelitian ini dapat direkomendasikan penggunaan chlorhexidine alkohol sebagai standar operasi tindakan antiseptik dan aseptik dalam pemasangan epidural dan standar operasi untuk mencegah infeksi pada pemasangan kateter epidural.

\section{Daftar Pustaka}

1. Darouiche R, Wall M, Itani $\mathrm{K}$, Otterson $\mathrm{M}$, Webb A, Carrick M. Chlorhexidine-alcohol versus povidone-iodine for surgical-site antisepsis. N Engl J Med. 2010;362:18-26.

2. Fernandes CR, Fonseca NM, Rosa DM, Simões CM, Duarte NMdC. Brazilian society of anesthesiology recommendations for safety in regional anesthesia. Rev Bras Anestesiol. 2011;61(5):668-94.

3. Hebl JR. The importance and implications of aseptic techniques during regional anesthesia. J Rapm. 2006;31(4):311-23.

4. Laporan Tahunan Anestesi. Bandung: Bagian Anestesiologi dan Terapi Intensif RSHS; 2013.

5. Hidayat I, Suwarman, Surahman E. Gambaran peta bakteri pada tip kateter epidural di Rumah Sakit Dr. Hasan Sadikin Bandung. Bandung: Universitas Padjadjaran; 2014.

6. Grewal S, Hocking G, Wildsmith JAW. Epidural abscesses. $\mathrm{Br} J$ Anaesth. 2006;96(3):292-302.

7. Yuan H, Zuo Z, Yu K, Lin W, Lee H. Bacterial colonization of epidural cathethers used for short-term postoperative analgesia: microbiological examination and risk factors analysis. Anesthesiology. 2008;108:130-7.

8. Sahay B, Dahake S, Mendriata D, Deotale V, Pramedran B, Narang P. Bacterial profile of 
epidural cathethers. JK Sci. 2010;12(1):236.

9. Bauer M, George JE, Seif J, Farag E. Recent advances in epidural analgesia. Anesthesiol Research Practice. 2012;1:1-14.

10. Horlocker TT, Wedel DJ. Infectious complications of regional anesthesia. Best Practice Research Clin Anaesthesiol. 2008:451-75.

11. Mimoz O, Villeminey S, Ragot S, Dahyot-Fizelier C, Laksiri L, Petitpas F. Chlorhexidine-based antiseptic solution vs alcohol-based povidone-iodine for central venous catheter care. Arch Intern Med. 2007;167(19):2066-72.

12. Kulkarni AP, Awode RM. A prospective randomised trial to compare the efficacy of povidone-iodine $10 \%$ and chlorhexidine $2 \%$ for skin disinfection. Indian J Anaesth. 2013;57(3):270-5.

13. Krobbuaban B, Diregpoke S, Prasan S, Thanomsat M, Kumkeaw S. Alcoholbased chlorhexidine vs. povidone iodine in reducing skin colonization prior to regional anesthesia procedures. J Med Assoc Thai. 2011;94(7):807-12.

14. Guzel A, Ozekinci T, Ozkan U, Celik Y, Ceviz
A, Belen D. Evaluation of the skin flora after chlorhexidine and povidone-iodine preparation in neurosurgical practice. Surg Neurol. 2007;71:207-10.

15. Katzung BG. Basic and clinical pharmacology. Edisi ke-10. San Francisco: McGraw Hill; 2006.

16. Cogen A, Nizet V, Gallo R. Skin microbiota: a source of disease or defence?. Br J Dermatol. 2008;158(3):442-55.

17. Hadzic A. Textbook of regional anesthesia and acute pain management. New York: McGraw-Hill; 2007.

18. Misrha S, Bhatnagar S, Srikati M. Clinical implication of routine bacterial culture from epidural catheters tip in postoperative cancer patients: a prospective study. Anesthesia. 2006;61(1):878-82.

19. Chlorhexidine Facts. 2012 [diunduh Desember 2012]. Tersedia dari: http:// chlorhexidinefacts.com tanggal 05/2014.

20. Kumar S, Babu R, Reddy J, Uttam. Povidone iodine-revisited. IJDA. 2011;3(3):617-20.

21. Rupp SM, Apfelbaum JL, Blitt C, Caplan RA, Connis RT, Domino KB. Practice guidelines for central venous access. Anesthesiology. 2012;116:539-73. 